\title{
Metamorphoses of the Subject: Kandinsky Interpreted by Michel Henry and Henri Maldiney ${ }^{1}$
}

\author{
Anna Yampolskaya \\ Higher School of Economics in Moscow \\ iampolsk@gmail.com
}

Received 3 April 2018; accepted 28 June 2018; published 30 September 2018.

\begin{abstract}
In this paper I compare how Michel Henry and Henri Maldiney interpret Kandinsky's heritage. Henry's phenomenology is based on a distinction between two main modes of manifestation: the ordinary one, that is, the manifestation of the world, and the "manifestation of life." For him, Kandinsky's work provides a paradigmatic example of the second, more original mode of manifestation, which is free from all forms of self-alienation. Henry claims that this living through the work of art is transformative; it is akin to ascetic practice or mystical experience that goes beyond the distinction of the subject and the object. Maldiney acknowledges Kandinsky's work as an attempt to provide access to an a-cosmic and ahistoric experience of one's inner self; yet for him this is not a positive characteristic. For Maldiney, the key distinction is not between modes of phenomenalisation, but between the dimensions of meaning (sens). For him there is no radical self-transformation which is not a transformation of one's being-in-the-world and one's meaning of the world, and so Kandinsky's a-cosmic paintings cannot induce a true transformation of the self. I conclude that the disagreement of Henry and Maldiney on Kandinsky does not unfold on the level of phenomenological description of concrete aesthetic experience, but on the level of metaphysics.
\end{abstract}

Keywords: aesthesis; French phenomenology; Henri Maldiney; Michel Henry; phenomenological aesthetics; Wassily Kandinsky.

\footnotetext{
${ }^{1}$ Support from the Basic Research Program of the National Research University Higher School of Economics is gratefully acknowledged.
} 
In this paper I compare how Michel Henry and Henri Maldiney interpret Kandinsky's heritage. This comparison is of some interest not only for the phenomenology of art: analysis of the disagreement between these two philosophers reveals that they actually agree as phenomenologists but disagree as metaphysicists. I start with Michel Henry and then proceed to Henri Maldiney. I conclude that for each of them the aesthetical experience implies radical transformation of the subject; the evaluation of this experience depends on how "genuine" this transformation is. The difference of the two approaches lies in the choice of metaphysical language and mystical metaphors employed to describe the metamorphosis of the subject.

To contextualise Henry's reading of Kandinsky's theoretical works, I need to sketch Henry's distinction of the two modi of appearing. Henry claims that the world appears not in the same way as life does: the appearing of the world and the appearing of the life are two different modi of appearing. His arguments can be roughly summarised as follows. I look at the things, or rather at the objects of the world, from a certain distance, as it were, from aside, as an external observer; I get access to myself from within, that is, in a totally different way. Although I can also perceive myself as if I was an object among many in the world - be it in a mirror that shows my body, or in the mirror of reflection that shows my thinking processes - I can also directly experience my inner life, that is, experience my own sensations and feelings. Henry seeks to overcome the dualism of the sensuous and the intelligible, the aesthetic (or "hyletic," to employ Husserlian terminology) and the noetic (that is, "animated" by the acts of consciousness), which Husserl inherited from British empiricism. According to Henry, Husserl ${ }^{2}$ attempts to reduce the richness of sensuous perception with its multi-layered affective fullness to the bare sensuous data, to the soulless matter, which has to be animated by the intentionality of consciousness (Henry, 2008, pp. 10, 13-15); Henry does not hesitate to classify it as philosophical "violence" or even "brutality" (Henry, 2008, p. 15). He concludes that the description of consciousness in terms of intentional structures - in terms of "the consciousness of..." - appears to be too rough. Intentionality, then, is not the general structure of consciousness and even less the basic structure of the subject. Intentional experience - inasmuch as an experience that presupposes a certain objectness (Gegenständlichkeit) and thereby imposes on this objectness some kind of norm - is but the most superficial of the layers of inner life. Anything of importance takes place deeper, on a non-intentional or pre-intentional level.

Pain, joy or anger are given to me from the inside, whereas the world is given to me from the outside, externally; but my "invisible" inner life, my perception of myself and my emotions are deeper than my experience of the world and its objectness. According to

\footnotetext{
${ }^{2}$ Henry's point of view is mostly based on the analysis of Husserl's lifetime publications; however, if one takes into account Husserl's posthumously published manuscripts, the situation starts looking considerably more complex. As was pointed out by Dan Zahavi, Husserl's views on the "hyletic sensations" underwent a number of transformations after Logische Untersuchungen and Ideen I, and in his later manuscripts he considered hyletic sensations no longer as inert and senseless but as "imbued with meaning" (Zahavi, 2003, p. 112).
} 
Henry, the intentional relation to the world in which hyletic data are 'animated' by corresponding acts of consciousness is marked by heterogeneity, ${ }^{3}$ that is, by "irreality" (Henry, 2008, p. 7, see also Henry, 2000, p. 76). ${ }^{4}$

Henry applies his theory to art. His book "Seeing the invisible: on Kandinsky" (Henry, 2009) is a philosophical reflection on the oeuvre of a great artist, written in 1988 in the best tradition of the French phenomenological aesthetics. For Henry, Kandinsky is first and foremost a painter of "the invisible" - the inner life - as opposed to life external, objective, representable. Kandinsky writes:

Every phenomenon can be experienced in two ways. These two ways are not arbitrary, but are bound up with the phenomenon - developing out of its nature and characteristics: Externally—or-inwardly. (Kandinsky, 1947, p. 17)

This opposition of the internal and the external, which opens Kandinsky's Point and line to plane, is interpreted by Henry as an opposition of two modi of manifestation: how the world appears and how life appears. One could say with Paul Klee that the goal of art is not to reproduce the visible, which Kandinsky calls "external," but to make visible the "internal," the invisible, which belongs not to the world but to the "night" of "absolute subjectivity" (Henry, 2009, p. 27). This does not mean, however, that the task of art is to transform the internal into the external, the invisible into the visible. Henry writes:

To paint is to show, but this showing has the aim of letting us see what is not seen and cannot be seen. The means of painting are the resources used for this showing and are employed in order to give us access to the invisible. (Henry, 2009, p. 10)

So, the task of painting is not painting the visible, but the invisible. The invisible must remain invisible, insists Henry, and the access to it granted to us by Kandinsky's pictures is not vision stricto sensu, but something rather different.

In other words, the teleology of art is similar to the teleology of intentionality in that its goal is to "make us see," but here we are talking about two very different types of "vision" as an access to a phenomenon. Vision as intentionality is a vision of something concrete, a vision of objects, not so much vision but perhaps recognition (as Viktor Shklovsky might have said, cf. Shklovsky, 1990, p. 10). Such vision is based on perception and thus on grasping the "sense" of a thing, its "essence," its self-identical character of an object. The variety of non-intentional sensuous data is "animated" and formed (or even "formatted") by a certain normativity of meaning (cf. Crowell, 2013): I can see a woman or a mannequin, I can see a mannequin and take it for a woman and then change my opinion, but I always see something definite. But a work of art, says Henry, does not aim to show us an object, that is, something definite - this cathedral or this apple, because it is definite only

\footnotetext{
3 "If two essences differ absolutely, together they cannot promote the homogeneity from which every reality draws its possibility" (Henry, 2008, p. 8).

${ }^{4}$ L. Tengelyi also acknowledges the irreal or fictitious character of Husserl's concept of experience, though for him this is not a negative feature (Tengelyi, 2007, p. 42).
} 
inasmuch as it is irreal. Instead, painting gives us access to the manifold, volatile, elusive, incoherent variety of sensuous data, to colours, hues, tints, light and shades:

What, then, is given in this visual experience to which one must return? Husserl says that the object is an ideal pole of identity over and above the multiplicity of its sensible appearances. That is why the painter does not really want to paint this ideal pole, this concept or entity which is always one and the same - the cathedral of Rouen or the haystack. Instead, the painter seeks these "sensible appearances" in their singularity and changes: this form with ungraspable contours and with faint lights that twinkle in the dazzling night, a bedazzlement where reality breaks down into pure bursts of blinding light, slips into the unknown, loses all consistency, and ultimately disappears (Henry, 2009, p. 15).

But unlike others, ${ }^{5}$ the aim of Kandinsky's painting is not a "return to true perception" (Henry, 2009, p. 15), not a reproduction of this "true perception" on a canvas. The task of Kandinsky is to recreate a certain experience in ourselves. Here, Henry's argument is in line with the well-known thesis that "art aims at impressing feelings on us rather than expressing them" (Bergson, 2001, p. 16). An engagement with a work of art awakens our emotions, makes happen an experience which is not an experience of something concrete, an experience which is not linked to a particular object that exists outside of me. Therefore, unlike the Impressionists who tried to reproduce perception in all its complexity on a canvas, Kandinsky's paintings are based not on perception but on "counter-perception" (Henry, 2009, p. 28): on the destruction of reference to an object. The intentional perception of a thing in its infinite horizon is replaced by the immediacy of a sensuous experience of colours and forms that "awaken in the subjectivity of the creator or the spectator" the multi-layered affective, or, in the words of Henry, the pathetic (pathétique) response (Henry, 2009, p. 39).

For such an experience we do not have and cannot have a name nor a language - in any case not a language based on ready-made ideal meanings separated from the living, embodied being which uses them for self-expression (Henry, 2003, p. 192). Such a language, a language of the world, is doomed for irrealisation and self-alienation, it can only be a "language of ideology," not a language of life, suffering, or passion (Henry, 2003, p. 192). We can illustrate Henry's thought by an example borrowed from Boris Pasternak's "The childhood of Luvers":

In the summer the Luvers lived in a country house on the other side of the Kama. [...] But what was going on, on the other shore of the river, in the far, far distance, she could not recognize; it had no name, no definite color or clear contours. Its billowing movements had

\footnotetext{
${ }^{5}$ Cf.: "The abstraction that releases the creative genius of Kandinsky has nothing to do with this type of abstraction that dominated the history of artistic creation starting from the second decade of the twentieth century and periodically returns under various guises. It would even be a contradiction of the worst kind to define it against these attempts - such as Cubism, Orphism, Futurism, Surrealism, Constructivism, Cinetism and Conceptualism - that never cease to relate to the visible as their sole object. They seek only to grasp the object's true nature and ultimately to grasp the true nature of visibility, whether it is sensible light (Impressionism) or transcendental (Mondrian, Malevich)" (Henry, 2008, p. 15).
} 
something dear and familiar about them; it was no nightmare like the one close by, which murmured in clouds of tobacco smoke and threw fresh, wind-tossed shadows on the reddish beams of the gallery. Zhenya [the child] started to cry. Her father came in and explained everything to her. Her English governess turned her face to the wall. The explanation was brief:

"That is Motovilikha. You should be ashamed of yourself. Such a big girl! Now go to sleep!"

The girl understood nothing and swallowed a salty tear. She had wanted only one thing, to know the name of the inconceivable: Motovilikha. That night the name explained everything and that night the name still held a real and reassuring meaning for the child. But in the morning she asked what Motovilikha was and what they made there at night. She learned that it was a factory, that it was owned by the government, that cast iron was made there, and that cast iron was made into. [...] But that did not interest her. (Pasternak, 1959, pp. 142-143)

A genuine, terrifying, but nameless experience of a small child is rendered harmless when the name "Motovilikha" (the name of a village) is attached to it by her father. The same device is used again at the end of the story when her new teacher erroneously gives the name of "love" to the nameless feeling that adolescent Zhenya has in regard to her deceased teacher, Tsvetkov. ${ }^{6}$ The author adds that the teacher was wrong: such feelings, such impressions do not have names; as Henry would put it, they cannot be expressed in the language of the world, but only in the language of life itself.

According to Henry, the language of colours and forms created by Kandinsky is not a language of the world, but is a language of flesh, a language of life. What is said in this language is not about life and not about emotions, but this language is emotions, is experience, is life; it is what is happening in us as we live it through. Mediation, which is proper to the traditional activity of language and to the traditional understanding of meaning, is by-passed: genuine art neither describes the world nor produces a system of transcendental references, but coincides with the very life of the subject of artistic perception (Henry, 2009, p. 73).

Henry sees in Kandinsky an Eckhartian mystic, ${ }^{7}$ who gives us an experience of "mystical knowledge" or "knowledge without objects" in an artistic form:

Art opens us to knowledge of an entirely different nature: it is a knowledge without object. Life is its ontological milieu, a life which embraces itself entirely without ever separating from itself and without being placed in front of itself like an object. (Henry, 2009, p. 18)

\footnotetext{
6 "The impression that was hiding behind all this in Zhenya's mind was indeed inexpungible. It was deeper even than he believed. The girl couldn't control this impression because it was important and vital to her; its importance lay in the fact that for the first time another human being had entered her life, the third person, without a name or with only a token name, who aroused neither hatred nor love, but what the Ten Commandments mean when they say: 'Thou shalt not kill. . . . Thou shalt not steal. . .' 'Thou, individual and living one,' they say, 'shalt not do to the unknown and the other what thou dost not wish done unto thyself.' Dikikh [another teacher] was much mistaken when he thought that impressions of this kind have a name. They have none. Zhenya cried because she believed she was responsible for all this" (Pasternak, 1959, p. 202).
}

${ }^{7}$ On Henry's interpretation of Eckhart see Depraz (2001). 
The creator's task is to share "emotions" with others, but not as just a particular affective experience - a "vibration of a soul," as Kandinsky puts it — but as a specific praxis, the praxis of the radical transformation of subjectivity. In other words, the reason that the aim of abstract art is not the "mimesis" of (emotional) life is the same reason that the aim of art is not the mimesis of the objective world (Henry, 2009, p. 120): abstract art does not reproduce the life of a soul on a painting, but produces it, brings it into action. "Art is the becoming of life, the way in which this becoming is carried out," says Henry (2009, p. 122). He quotes the famous passage from Kandinsky's Cologne lecture: "I do not want to paint states of mind [Seelenzustände]" (1994, p. 400). For Henry, this means that Kandinsky's abstract art is the epiphany of Life itself; it does not "reproduce" Life but "resurrects" it. This thought of Henry can be illustrated with the following example. We experience colours and forms in exactly the same way as pain, cold or joy: by determining that a fragment of a painting is objectively red we perform an artificial act of alienation. One can notice that we directly benefit from such an alienation: by shifting the focus from myself to a thing I take myself out of action and can forget about myself and my perception of this red. The noematic objectivity of this red becomes a protective wall between the self and the self. The perception of art is a spiritual praxis because it requires us to abandon this defence, to accept our vulnerability, to recognise our feelings: what is in front of me is not a harmless "objectively red" canvas - this smudge of red colour frightens me or makes me joyful or anxious. Such is the $\pi \alpha \dot{\theta} \theta$ o $\varsigma$ of the affective life! In this sense, the truth of art is indeed "practical" and even "ethical": by engaging with a work of art we perform a certain act of self-abandon which is at the same time an act of self-realisation of life. In the words of the Russian poetess Maria Stepanova one could say that "life continues itself" in a true art.

Henry Maldiney sees Kandinsky's art in a totally different light. He describes it as "aesthetical euclidism," as a dry and soulless "catalogue of forms of consciousness," as an "alphabet of affects" (Maldiney 2013, 106-107). On the one hand, the theoretical positions of Henry and Maldiney have much in common: like Henry, Maldiney understands intentionality only as a derived form of the life of consciousness; like Henry, he emphasises the importance of sensuous and affective experiences; like Henry, he proposes rejecting the Kantian epistemological setting in which the original cognition takes place through an active experience, and introducing the notion of passive experience (épreuve). On the other hand, the approaches of Henry and Maldiney are quite different, as witnessed by their diverging views on Kandinsky. Let us look more precisely at this difference.

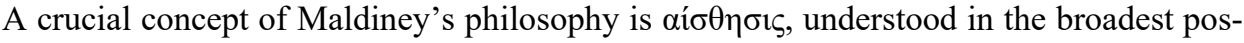
sible sense: "sensing" and "having an aesthetical experience" mean almost the same to him. Maldiney borrows the notion of sensing from the German psychiatrist Erwin Straus and modifies it. Sensing (das Emfinden, le sentir) means not so much "to perceive through senses" but "to experience," to "live through"-non-intentionally, before any objectification or structuring, before any project (Entwurf). When I sense and feel, I make contact 
with the world as the world and not with the world as a collection of objects - I relate to the things without objectifying them. ${ }^{8}$

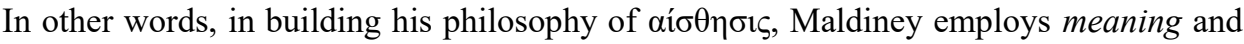
not phenomenon as his second basic concept. While Henry talks about reaching a new, deeper mode of appearing, Maldiney tells us about another, more fundamental level of meaning — not "gnostic" but "pathic." This is not an objective or noematic meaning, because "it does not concern what, it concerns how" (Maldiney, 2013, p. 190); it cannot be directly expressed "in thematisation and within the horizon of the possible" (Maldiney, 2013 , p. 190), in words, but only in a "scream" "which has no definite meaning. Nevertheless, it has a meaning of a sort which refers to the broad horizon of usual, cognitive, "gnostic" meanings. This meaning is referential, and referentiality is proper to the meaning in general. However, the reference here is made not to a determined object, but to the world at the moment of its becoming a known and comprehensible world, ${ }^{10}$ to a world "that has not yet crystallised in objects" (Maldiney, 2013, p. 191).

In the notion of $\alpha i \sigma \theta \eta \sigma ı \varsigma$, Maldiney unites the pathic, studied by Viktor von Weizsäcker and Erwin Straus, ${ }^{11}$ with the original sensation (ursprüngliche Empfindung), as described by Hölderlin in the following manner: genuine sensing of the world is indistinguishable from the poetic attitude to which the world appears as if "for the first time," new and "unexplored," not yet grasped or well-defined (Hölderlin, 1962, p. 263, for more details on Hölderlin's influence on Maldiney see Goddard, 2008). This original sensation, or proto-impression, to employ the Husserlian term used by Maldiney to translate Hölderlin, is not an isolated experience but a way to relate to the self and to the world as a whole: a double operation where by changing my being in the world I gain access to myself, and by transforming myself I gain access to the world (Maldiney, 1991, pp. 198-199). Thus,

\footnotetext{
8 "Experiencing is synonymous with experiencing-the-world and with experiencing-oneself-in-the-world. It is directed to the Other; but one experiences the Other only in relation to oneself and vice versa. Experiencing is of the I-World relation. This relation, which is not a compound of two parts- I and the World-but exists only as a whole, cannot be translated into or replaced by the sequence "stimulus and response"' (Straus, 1960, p. 312, see also Straus, 1978, p. 372).

${ }^{9}$ Here Maldiney again refers to Erwin Straus (1978, p. 329). The scope of this work does not allow us to go deeper into the comparison of their views; let us only point out that they are far from identical.

${ }^{10}$ This moment of inchoativeness, emphasised by Maldiney (and Merleau-Ponty), plays a crucial role in Marc Richir's phenomenology, in which the "the meanings in statu nascendi" are the main focus of analysis.

${ }^{11}$ Cf.: ,Wir beziehen also das pathische Moment, das sei ausdrücklich hervorgehoben, nicht auf die Gegenstände mit ihren festen oder verschiedenen Eigenschaften, also nicht auf die Gegenstände, die uns wegen dieser Eigenschaften etwa locken, schrecken oder bedrücken könnten. Würden wir das pathische Moment an die Gegenstände knüpfen, dann hätten wir es ja wieder dem Bereich des Begrifflichen eingeordnet und die Unterscheidung von gnostisch und pathisch bereits wieder rückgängig gemacht. Das Pathische gehört aber gerade zu dem Bestand des ursprünglichsten Erlebnis; es ist darum der begrifflichen Erkenntnis so schwer zugänglich, weil es selbst die unmittelbar-gegenwärtige, sinnlich-anschauliche, noch vorbegriffliche Kommunikation ist, die wir mit den Erscheinungen haben“" (Straus, 1960, p. 151).
} 
for Maldiney, the non-intentionality of sensing does not imply a departure from "the phenomenality of the things." In the mood as a form of being-in-the-world, in the emotional experiences, in joy or sadness, in anxiety or confidence - ontologically understood - we are genuinely in "communication with the world" in its inchoative form (Maldiney, 2013, p. 141). On the contrary, the volatility of emotions, the mood swings - if they come solely from the inner life of the subject - seem somewhat morbid or pathological to Maldiney.

Maldiney, very much like Henry, sees the essence of Kandinsky's aesthetical theory in the opposition of the external and the internal, but for him this is a sign of pathology. The works of Kandinsky affect and impress us because of the "isomorphism" he has discovered between "pictorial (graphic or chromatic) components of a painting and the elementary components of affectivity" (Maldiney, 2013, p. 107). Maldiney is outraged by Kandinsky's suggestion that the "modern man deafened by external noises" will find his "repose" in "the inner silence." Maldiney reads "being-in-the world" as "being-to-the-world" (Maldiney, 2013, p. 108), so when Kandinsky turns away from the external in order to embrace the internal he renounces the world and no longer cares for it. The subjectivity is no longer understood as transcending to the world and becomes a kind of object. Maldiney interprets Kandinsky's aesthetical theory as an attempt to translate the pathic into the language of eidetic intuition, the language of Wesenschau (Maldiney, 2013, p. 157), but such a translation inevitably leads to the "objectification" of affectivity, to the "objectivism of essences" (Maldiney, 2000, p. 180). Art cannot be other than factitious, other than awakening in me a reference to the world and to my "here" in this world; but the language of essence spoken by Kandinsky's pictures is "the language of the unconscious," the language of dreams, unrelated to any particular time or a place (Maldiney, 2012, pp. 124 125; Maldiney, 2013, p. 163). Having freed itself from the object, non-objective art seeks to replace the direction to the object by the intuition of essences (Maldiney, 2000, p. 180). However, the ideal objects in Kandinsky's pictures are precisely outlined and well delineated: the "tension" which is discussed by Kandinsky in his writings and which is present in his pictures is a purely spatial, not a temporal, tension (Maldiney, 2013, p. 157); the temporality of Kandinsky's pictures is reduced to "continued instantaneity" and thus resembles deficient a-historic temporality of psychotic existence (Maldiney, 2013, p. 108, cf. also Maldiney, 2000, p. 100). "The new objectivism of abstract compositions" is "without memory and without history," Maldiney disapprovingly concludes his analysis (Maldiney, 2013, p. 107).

Kandinsky's art is “indifferent to history," agrees Michel Henry:

Kandinsky situates the object of his theoretical reflection outside of history: the eternal essence of life is the principle behind all art and painting. It is precisely because this essence is eternal that it is indifferent to history (even if it founds history at each instant) and that the artworks proceeding from it also exceed the historical categories and mental habits through which they are customarily approached. (Henry, 2009, p. 126)

Henry interprets Kandinsky's indifference to history as a freedom from history and an exit into the dimension of eternity. Although "at this moment in history" we are accustomed 
to historical analysis as a principal mode of access to the true sense of works of art, the essence of art, like the essence of life, is eternity and not history (Henry, 2009). We, the living, experience life. The essence of pathetic subjectivity awakened by art consists precisely in this experiencing, in the passivity of life in regard to itself. Kandinsky's art, says Henry, reveals to us the essence of life which has a different - atemporal-mobility, a mobility of force:

A new dynamism emerges with sharply cut out forms whose arrangements establish extraordinary equilibriums, give birth to a play of tensions, openings, and advances confronted with subtle counter-attacks, and are broken apart by some ideal line or an indifferent, self-absorbed and invincible sphere. Force is no less great when it dwells in this atemporal confrontation of arrows, curves, opposed or joined angles and geometrical planes barely tinted with a vague light (Henry, 2009, p. 47).

The dialectics of life does not mean an ecstatic exit from the self, nor does it mean selfnegation; its prototype is the alchemical transformation of lead into gold and not the opposition of that which was to that which is. ${ }^{12}$ The transformation of sadness into joy or suffering into delight does not suggest a negation, the annulment of the preceding phase of affective life, or the replacement of that which was by that which is. The life of a soul, like Divine Life, knows no alienation ${ }^{13}$ : bread and wine become Body and Blood without ceasing to be bread and wine. Such is the spiritual transformation caused in us by Kandinsky's paintings, says Henry: the transformation of subjectivity does not obey the law of the excluded third.

Maldiney's approach to the transformation of the subject is completely different: for him this is a rapture, a dramatic re-arrangement of the structures of meaning. The transformation of the subject is always a catastrophe, a revolution, an event that can be appropriated only because the life of the subject has gaps and hiatuses. One could say that a subject has lived through a radical transformation only if her or his way of being-in-the-world has changed. A possible source of such a shake-up is sensing, which is a "pathic moment": Aeschylus says that "suffering teaches" because $\pi \alpha$ ó $\theta \zeta$ is full of meaning (Maldiney, 2013,

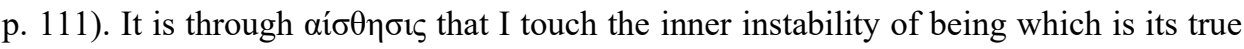
reality (as opposed to the objectified, stabilised form of being). The work of art, which is a rhythmically organised form of $\alpha i \sigma \theta \eta \sigma i \varsigma$, confronts the subject with the unforeseeable: gaps, lacunas, discontinuities (Maldiney, 2012, pp. 130-133). In other words, the aesthetical experience opens up the world thanks to the experience of misunderstanding, the experience of failed expectations. It is exactly this experience of failed expectations,

\footnotetext{
${ }^{12} \mathrm{Cf}$ :: "By claiming to make gold out of lead, alchemy implies directly as the prior theoretical presupposition supporting its practical undertaking that the ground of reality is not made up of fixed things, of immutable elements, but that it is instead change. Or again: change cannot be understood as the mere substitution of one element for another, as replacing one body with another" (Henry, 1983, p. 71).

${ }^{13}$ Luther translated that Christ "humbled himself" (Phil. 2,7) as "hat sich selbst geeussert." According to Henry, this translation influenced the understanding of kenosis as "production of objectivity" and ultimately as "alienation" (Henry, 1983, pp. 75, 78), shared by a number of German thinkers. This interpretation was then extended to the transformation of any lived experience and, more broadly, of the inner life in general.
} 
breakdown and reconstruction of the structures of meaning that Maldiney misses in the works of Kandinsky: these pictures seem too harmonious, the sovereign design of the artist is too obvious in them (Maldiney, 2000, pp. 187-188). Their very perfection is a kind of defect: nothing is lacking in them (Maldiney, 2000, p. 272), and this lacking lack brings anxiety (Maldiney, 2013, p. 108) which reflects the claustrophobic, almost schizophrenic experience of control of the world and the self.

So, both Henry and Maldiney agree that Kandinsky's painting is an art free from the experience of the world and the experience of time; the unsettling impact of his works is due to radical auto-affection that does not imply communication with the world. Those who live through his works properly ${ }^{14}$ undergo a specific atemporal and ahistorical transformation. It appears that the disagreement of Henry and Maldiney in their evaluation of Kandinsky's work is due to their metaphysical divergence. Each of them tacitly assumes that he knows the "true" meaning of radical transformation of the subject. For Maldiney, an aesthetical event radically transforms the very being-in-the-world, blowing up the structure of projects and expectations, possibilities and impossibilities, generating a "new world" with its own spatiality and temporality. The subject is transformed alongside her world, which is brought forward by the event. For Henry, transformation of the subject is due to the essential mobility of inner life; the changes of inner life have no history and involve no negation. However, phenomenology should not accept the leadership of metaphysics. An intrusion of metaphysical presuppositions into phenomenological work is a permanent temptation; within the framework of individual research, the certain use of metaphysical language may well be unavoidable when dealing with sufficiently complex reality. This is why the collective nature of phenomenological work is so important: it allows the community of phenomenologists to correct each other and thus to distil phenomenological description proper from the metaphysical language in which it is expressed.

\section{References}

Bergson, H. (2001). Time and free will: An essay on the immediate data of consciousness. (F. L. Pogston, Trans.). New York, NY: Dover.

Crowell, S. (2013). Normativity and phenomenology in Husserl and Heidegger. Cambridge, UK: Cambridge University Press.

Depraz, N. (2001). En quête d'une métaphysique phénoménologique: La référence henrienne à Maître Eckhart. In J. Greisch \& A. David, Eds., Michel Henry, l'épreuve de la vie: Actes du Colloque de Cerisy-la-Salle, 1996 (pp. 255-279). Paris, France: Cerf, La nuit surveillé.

Goddard, J.-C. (2008). Violence et subjectivé: Derrida, Deleuze, Maldiney. Paris, France: Vrin.

\footnotetext{
14 “Apart from my theoretical works, which until now from an objective, scientific point of view leave much to be desired, I only want to paint good, necessary, living pictures, which are experienced properly by at least a few viewers" (Kandinsky, 1994, p. 400).
} 
Henry, M. (1983). Marx: A philosophy of human reality. Bloomington: Indiana University Press.

Henry, M. (2003). Phénoménologie de la vie, Vol.1, De la phénoménologie. Paris, France: Presses Universitaires de France.

Henry, M. (2008). Material phenomenology. (S. Davidson, Trans.). New York, NY: Fordham University Press.

Henry, M. (2009). Seeing the invisible: On Kandinsky. (S. Davidson, Trans.). London, UK: Continuum. For French original see: Henry M. (2005). Voir l'invisible: Sur Kandinsky. Paris, France: Presses Universitaires de France.

Hölderlin, F. (1962). Wink für die Darstellung und Sprache. In F. Hölderlin, Sammliche Werke / heraus. von F. Beissner. 6 Bände, Band 4. Stuttgart, Germany: W. Kohlhammer

Kandinsky, W. (1947). Point and line to plane. (H. Dearstyne \& H. Rebay, Trans.). New York, NY: Guggenheim Foundation.

Kandinsky, W. (1994). Kandinsky, complete writings on art. (K. C. Lindsay \& P. Vergo, Eds.). New York, NY: Da Capo Press.

Maldiney, H. (1991). Penser l'homme et la folie. Grenoble, France: Éditions Jérôme Million.

Maldiney, H. (2000). Ouvrir le rien, l'art nu. La Versanne, France: Encre Marine.

Maldiney, H. (2012). L'art, l'éclaire de l'être. Paris, France: Cerf.

Maldiney, H. (2013). Regard, Parole, Espace. Paris, France: Cerf.

Pasternak, B. (1959). The Childhood of Luvers. In B. Pasternak Safe conduct: An autobiography and other writings. New York, NY: The New American Library.

Shklovsky, V. (1990) Theory of Prose. (B. Sher, Trans.). Elmwood Park, IL: Dalkey Archive Press.

Straus, E. (1960). Psychologie der menschlichen Welt. Berlin, Germany: Springer.

Straus, E. (1978). Vom Sinn der Sinne: Ein Beitrag zur Grundlegung der Psychologie (2nd ed.). Berlin, Germany: Springer.

Tengelyi, L. (2007). Erfahrung und Ausdruck: Phänomenologie im Umbruch bei Husserl und seinen Nachfolgern. Phaenomenologica, 180. Dordrecht, the Netherlands: Springer.

Zahavi, D. (2003). Husserl's phenomenology. Stanford, CA: Stanford University Press. 